(c) American Dairy Science Association, 2003.

\title{
Effects of Various Glucogenic Sources on Production and Metabolic Responses of Dairy Cows Fed Grass Silage-Based Diets
}

\author{
A. Vanhatalo, T. Varvikko, and P. Huhtanen \\ MTT, Agrifood Research Finland, Animal Production Research, \\ FIN-31600 Jokioinen, Finland
}

\begin{abstract}
Four rumen cannulated Finnish Ayrshire cows in midlactation were used in an experiment designed as a $4 \times 5$ incomplete Latin square with 2 -wk periods to compare effects of glucogenic substrates on grass silage-based diets. The five treatments were continuous infusions of 1) water (control), 2) casein $300 \mathrm{~g} / \mathrm{d}$, 3) glucose $300 \mathrm{~g} / \mathrm{d}, 4)$ propionic acid $247 \mathrm{~g} / \mathrm{d}$, and 5) barley starch $270 \mathrm{~g} / \mathrm{d}$. Substrates were infused either into the rumen (propionic acid) or into the abomasum (other substrates). As a basal diet, cows were fed a formic acid treated grass silage ad libitum (digestible organic matter $690 \mathrm{~g} / \mathrm{kg}$ dry matter [DM], crude protein $[\mathrm{CP}] 131 \mathrm{~g} / \mathrm{kg} \mathrm{DM}$ ) and a barley-rapeseed concentrate $(\mathrm{CP} 141 \mathrm{~g} / \mathrm{kg} \mathrm{DM})$ at a rate of $7 \mathrm{~kg} / \mathrm{d}$. Production responses to glucogenic substrates other than casein were negligible, suggesting that glucose supply of the cows did not primarily limit milk production. However, with casein cows produced significantly more milk, milk protein, and lactose than with other glucogenic substrates. Casein increased urea and essential amino acid (EAA), and decreased nonessential AA (NEAA) in arterial plasma compared with other substrates, suggesting that casein provided precursors both in terms of NEAA for gluconeogenesis and EAA for milk protein synthesis. This puts forward that providing the AA needs of the mammary gland for milk protein synthesis are met, glucose supply may become the next limiting factor for milk protein synthesis in cows fed diets based on restrictively fermented grass silage. The limited supply of AA from the basal diet, and possibly the low production levels of cows partly invalidated the hypothesis of monitoring differing glucogenic substrates for grass silage-based diets.
\end{abstract}

(Key words: grass silage, glucogenic sources, dairy cow, amino acids)

Abbreviation key: AV = arteriovenous, EAA = essential amino acids, $\mathbf{G}=$ glucose, $\mathbf{N E A A}=$ nonessential

Received October 2, 2002.

Accepted April 30, 2003.

Corresponding author: A. Vanhatalo; e-mail: aila.vanhatalo@ mtt.fi. amino acids, $\mathbf{P}=$ propionic acid, $\mathbf{S}=$ barley starch, TAA $=$ total amino acids.

\section{INTRODUCTION}

In Finland, dairy cow feeding has long been based on abundant use of formic acid-preserved grass silage and moderate levels of grain-based supplements, a combination favoring a rumen fermentation pattern high in lipogenic VFA and low in propionate (Huhtanen, 1998). High ruminal butyrate production can have adverse effects on glucose $(\mathbf{G})$ production and lactose synthesis (Miettinen and Huhtanen, 1996). As the proportion of propionate in the rumen VFA is small on these diets, they may not provide sufficient gluconeogenic precursors to high-yielding dairy cows (Miettinen, 1997; Huhtanen, 1998). Huhtanen et al. (1998) obtained a higher protein yield with intraruminal propionate infusion than with intraruminal isoenergetic butyrate infusion, suggesting that milk protein yield was limited by G supply. This is further supported by the results of the recently reported study (Huhtanen et al., 2002), in which postruminally infused G in combination with His produced a substantial increase in milk protein yield, whereas increases in protein yield were only moderate when G or His were infused separately.

In principle, manipulating the $\mathrm{G}$ supply of cows may be done either by increasing the proportion of propionate in rumen VFA or by increasing G supply to the intestines. However, manipulation of rumen fermentation pattern of grass silage-based diets is challenging. The proportion of propionate in rumen VFA can be increased by using biological additives, producing high-lactate silage (Chamberlain and Choung, 1993; van Vuuren et al., 1995; Huhtanen, 1998), but this type of silage does not support microbial protein production as high in the rumen as does silage ensiled with acid additives (Jaakkola and Huhtanen, 1993; van Vuuren et al., 1995). On the other hand, the high protein value of the latter silage may be compromised because part of the AA of microbial origin may be used for gluconeogenesis. This might explain why lowered 
plasma $\mathrm{G}$ and enhanced BHBA are features of cows given restrictively fermented silage (Miettinen, 1997).

Enhancing propionate production in the rumen or $\mathrm{G}$ supply to the intestines by increasing the amount of grain in the diet is also difficult with grass silagebased diets. Increasing the proportion of barley-based concentrate up to 0.75 in the diet increased butyrate instead of propionate (Jaakkola and Huhtanen, 1993). Barley starch is also known to be more rapidly and extensively degradable in the rumen than other starch sources, such as corn starch (Nocek and Tamminga, 1991). However, in theory, it should be favorable to shift starch digestion towards the intestines because there is evidence that starch digested postruminally is used more efficiently for milk synthesis than that digested in the rumen (Nocek and Tamminga, 1991).

The objectives of the present experiment were 1) to study the role of $\mathrm{G}$ as a limiting factor for milk protein synthesis on diets containing a high proportion of restrictively fermented grass silage supplemented with a barley-based concentrate, and 2) to study whether the supply of $\mathrm{G}$ on this type of diet should be enhanced by increasing production of propionic acid in the rumen, or by increasing the postruminal supply of G. Propionic acid infused ruminally, and $G$ and starch infused postruminally were compared as isoglucogenic amounts of $\mathrm{G}$ sources. In addition, $\mathrm{CN}$ was infused postruminally to compare responses to equal amounts of $\mathrm{AA}$ and $\mathrm{G}$.

\section{MATERIALS AND METHODS}

\section{Animals, Management, and Feeds}

Four rumen-cannulated Finnish Ayrshire cows (114 to 117 DIM) in their fourth or fifth lactation were used in the experiment. Their average BW was $554 \pm 75 \mathrm{~kg}$ at the beginning of the experiment, and $546 \pm 76 \mathrm{~kg}$ at the end of the experiment. Infusion catheters were introduced into the abomasum as described earlier (Varvikko et al., 1999). The cows were housed individually in metabolism stalls and milked twice daily at 0700 and $1630 \mathrm{~h}$. As a basal diet, the cows were fed a formic acid-treated grass silage ad libitum and a concentrate consisting of crushed barley $(82.4 \%)$, solvent-extracted rapeseed meal (14.3\%; Rehuraisio Oy, Raisio, Finland) and commercial mineral mixture (3.3\%; Viher Hertta-Minera, Suomen Rehu Oy, Helsinki, Finland) at a rate of $7 \mathrm{~kg} / \mathrm{d}$ on a fresh weight basis. The level of protein supplementation in the concentrate was adjusted to provide sufficient $\mathrm{N}$ supply for rumen microbes, but also to avoid substantial supply of bypass protein in the diet. It was thought that the bypass protein could possibly provide incremental AA for gluconeogenesis and milk protein synthesis, and thus obscure effects of increased G supply. Grass silage was offered four times a day to allow refusals of $10 \%$ of the total consumption, and concentrates were given twice a day at milking times in two equal meals. The cows had free access to water and salt block. Grass silage was prepared from a second-cut timothy (Phleum pratense) and meadow fescue (Festuca pratensis) sward. The grass was cut with a disc-mower and harvested after a wilting period of 4 to $6 \mathrm{~h}$ with a precision-chop forage harvester. The grass was ensiled in a bunker silo with a formic acid-based additive (800 $\mathrm{g}$ of formic acid and $20 \mathrm{~g}$ of orthophosphoric acid per kilogram of additive), applied at the rate of $5.0 \mathrm{~L} /$ tonne of grass.

\section{Experimental Design and Treatments}

The experiment was designed as a $4 \times 5$ incomplete Latin square with 14-d periods, of which the last $7 \mathrm{~d}$ formed a collection period. The five treatments allocated to four animals were continuous infusions of 1 ) water (control), 2) $300 \mathrm{~g} / \mathrm{d}$ of CN, 3) $300 \mathrm{~g} / \mathrm{d}$ of G, 4) $247 \mathrm{~g} / \mathrm{d}$ of propionic acid (P), and 5) $270 \mathrm{~g} / \mathrm{d}$ of barley starch (S). Casein and $\mathrm{G}$ were given in equal amounts, but the other treatments were calculated to be isoglucogenic to treatment $\mathrm{G}$ on the basis of carbon equivalence. The amount of $\mathrm{G}$ infused in the study was calculated to support an increment of approximately $4 \mathrm{~kg}$ of milk based on the estimated requirement of $\mathrm{G}$ for $70 \mathrm{~g} / \mathrm{kg}$ of milk (Danfær et al., 1995). Six liters of water on control treatment, and substrates, except for $\mathrm{P}$, stirred in $6 \mathrm{~L}$ of water were continuously infused into the abomasum using a peristaltic pump (Watson Marlow, Falmouth, Cornwall, UK). Infusion equipment was checked daily during the experiment to ensure correct placement in the abomasum. Casein was given as sodium caseinate (Kainuun Osuusmeijeri, Sotkamo, Finland) and G as dextrose (Xyrofin Ltd, Helsinki, Finland). Barley starch was provided by Primalco Ltd., Koskenkorva, Finland. Propionic acid (Hankkija Maatalous, Finland), partially neutralized with $150 \mathrm{ml}$ of $5 \mathrm{M} \mathrm{NaOH}$, was diluted in $20 \mathrm{~L}$ of water and infused into the rumen. Sodium from $\mathrm{NaOH}$ for the experimental treatments was balanced with $\mathrm{NaCl}$.

\section{Sampling and Recordings}

Feed intake and milk yield were recorded daily. For statistical analysis, the results of the last $7 \mathrm{~d}$ of each experimental period were used. Milk samples were taken on four consecutive milkings, starting on the evening of d 11 of each period. Another milk sample from evening and morning milking was taken for urea determination. Feeds were sampled at regular inter- 
vals throughout each period and pooled for subsequent chemical analysis. Rumen fluid was sampled four times a day, and blood from one superficial epigastric (mammary) vein and one coccygeal (tail) vessel three times a day, each at 3-h intervals starting just before the morning feeding on the last day of each experimental period. A blood sample from the tail vein is considered to represent arterial blood as metabolism in the tail is assumed to be insignificant. Rumen fluid samples and plasma samples were pooled over the sampling times to provide one sample per cow per day for analysis. To evaluate the energy status of the cows, the total digestibility of diets was measured using acidinsoluble ash as an internal marker. A 5-d fecal grab sampling was carried out for this purpose. Further details on all samplings were described earlier (Varvikko et al., 1999; Vanhatalo et al., 1999b).

\section{Chemical Analyses}

The chemical composition of feeds and feces were analyzed as described earlier (Varvikko et al., 1999; Vanhatalo et al., 1999b). Details of the procedures for VFA of rumen fluid and colorimetrically analyzed plasma G and NEFA, as well as plasma AA were described in our previous paper (Varvikko et al., 1999). Blood BHBA was analyzed with KONE Specific analyzer (KONE Instruments Corp., Espoo, Finland) by the method of Hansen and Freier (1978). Details of the procedures as well as analyses on milk for contents of protein, fat, lactose, and urea are described in our previous paper (Varvikko et al., 1999).

\section{Calculations and Statistical Analyses}

Mammary extraction and uptake of blood metabolites and AA and plasma flow were calculated as described earlier (Vanhatalo et al., 1999b). In brief, mammary extraction efficiency of blood metabolites and AA were calculated as arteriovenous (AV) difference divided by arterial concentration. Mammary plasma flow was estimated in reference to Phe and Tyr output in milk protein by application of Fick principle. This approach assumes that Phe and Tyr are incorporated directly into milk protein without no further metabolism or synthesis of these two AA.

Data were analyzed by analysis of variance for Latin square: cow ( $\mathrm{df} 3$ ), period ( $\mathrm{df} 4)$, treatment ( $\mathrm{df} 4)$, and the residual effects ( $\mathrm{df} 8$ ) were the sources of variation. The general linear models procedure of SAS (1996) was used. Treatment effects were further separated into a single degree of freedom comparisons by orthogonal contrasts as follows: 1 ) control versus all $G$ substrates (control vs. $\mathrm{CN}+\mathrm{P}+\mathrm{G}+\mathrm{S}$ ), 2) AA versus other
Table 1. The chemical composition of the feedstuffs.

\begin{tabular}{lcc}
\hline & Grass silage & Concentrate $^{1}$ \\
\hline $\mathrm{pH}$ & 4.24 & \\
$\mathrm{DM}, \%$ & 32.6 & 88.1 \\
\cline { 2 - 3 } Ash & 9.2 & 6.1 \\
Total N & 2.09 & 2.25 \\
NDF & 52.0 & 26.0 \\
Water-soluble carbohydrates & 11.6 & \\
Lactic acid & 3.7 & \\
Acetic acid & 1.3 & \\
Propionic acid & 0.003 & \\
Butyric acid & 0.012 & \\
Ammonia N, \% of soluble N & 4.1 & \\
Soluble N, \% of total N & 51.7 & \\
In vitro cellulase digestibility, & & \\
\% of OM & 76.0 & \\
\hline
\end{tabular}

${ }^{1}$ Concentrate was a mix of barley $(82.4 \%)$, rapeseed meal $(14.3 \%)$ and minerals $(3.3 \%)$. The mineral mixture given contained $16 \%$ of $\mathrm{Ca}, 6.4 \%$ of $\mathrm{P}, 9 \%$ of $\mathrm{Na}$ and $8 \%$ of $\mathrm{Mg}, 150,000 \mathrm{IU}$ of vitamin $\mathrm{A} / \mathrm{kg}$, $100,000 \mathrm{IU}$ of vitamin $\mathrm{D} / \mathrm{kg}$, and $500 \mathrm{mg}$ of vitamin $\mathrm{E} / \mathrm{kg}$. It also contained trace elements as follows (per $\mathrm{kg}$ ): $500 \mathrm{mg}$ of $\mathrm{Cu}, 10 \mathrm{mg}$ of Se, $3000 \mathrm{mg}$ of $\mathrm{Zn}, 8 \mathrm{mg}$ of Mo, $10 \mathrm{mg}$ of Co, $1000 \mathrm{mg}$ of $\mathrm{Mn}$, and $100 \mathrm{mg}$ of I.

G substrates (CN vs. $\mathrm{P}+\mathrm{G}+\mathrm{S}), 3$ ) ruminally versus postruminally supplied $G$ substrates ( $P$ vs. $G+S$ ), and 4) comparison of $G$ substrates supplied within intestine (G vs. S).

\section{RESULTS}

Grass silage used in the experiment was of good quality and restrictively fermented in the silo, as indicated by low concentrations of total acids and ammonia $\mathrm{N}$, and high concentration of water-soluble carbohydrates (Table 1). The CP content of grass silage (131 $\mathrm{g} / \mathrm{kg} \mathrm{DM}$ ) was relatively low, but D-value (69\%), based on measurement of in vitro cellulase digestibility, was reasonably high. Data on feed intake and rumen fermentation are presented in Table 2. Substrates infused did not affect grass silage intake. However, except for P treatment, cows tended to refuse some of the concentrates, especially on $\mathrm{S}$ treatment. For this reason total DM and metabolizable energy intakes were significantly lower on $\mathrm{S}$ than on G treatment ( $P$ $<0.01$ ). Substrates infused did not affect rumen $\mathrm{pH}$ $(P>0.05)$. Rumen ammonia $\mathrm{N}$ concentration was low and further reduced $(P<0.01)$ with infused substrates compared with control ( $2.25 \mathrm{vs} .3 .77 \mathrm{mmol} / \mathrm{L})$. Infused substrates also slightly decreased concentrations of total VFA $(P<0.05)$. Except for $\mathrm{P}$ treatment, rumen fermentation patterns were typical for cows fed restrictively fermented silage (Huhtanen, 1998). Infusion of $P$ resulted in significantly lower $(P<0.05)$ proportions of acetate and butyrate, and a higher $(P<0.001)$ proportion of propionate in the rumen than infusions of 
Table 2. Least squares means for feed intake and rumen fermentation of experimental diets.

\begin{tabular}{|c|c|c|c|c|c|c|c|c|c|c|}
\hline & \multicolumn{6}{|c|}{ Nutrients infused ruminally or postruminally ${ }^{1}$} & \multicolumn{4}{|c|}{ Contrast $(P)^{2}$} \\
\hline & Control & $\mathrm{CN}$ & $\mathrm{P}$ & G & $\mathrm{S}$ & SEM & 1 & 2 & 3 & 4 \\
\hline \multicolumn{11}{|l|}{ DMI, kg/d } \\
\hline Silage & 10.5 & 10.5 & 10.5 & 10.8 & 10.5 & 0.22 & $\mathrm{NS}^{3}$ & NS & NS & NS \\
\hline Concentrate & 5.9 & 5.8 & 6.2 & 6.0 & 5.4 & & & & & \\
\hline Total & 16.4 & 16.4 & 16.7 & 16.8 & 15.9 & 0.22 & NS & NS & NS & $* *$ \\
\hline $\begin{array}{l}\text { Metabolizable energy intake, } \\
\text { MJ/d }^{4}\end{array}$ & 184 & 184 & 185 & 189 & 177 & 2.1 & NS & NS & NS & $* *$ \\
\hline \multicolumn{11}{|l|}{ Rumen fermentation } \\
\hline $\mathrm{pH}$ & 6.33 & 6.30 & 6.42 & 6.39 & 6.35 & 0.119 & NS & NS & NS & NS \\
\hline $\mathrm{NH}_{3}-\mathrm{N}, \mathrm{mmol} / \mathrm{L}$ & 3.77 & 1.89 & 2.29 & 2.88 & 1.92 & 0.388 & $* * *$ & NS & NS & NS \\
\hline $\begin{array}{l}\text { VFA, } \mathrm{mmol} / \mathrm{L} \\
\text { VFA, } \mathrm{mmol} / \mathrm{mol}\end{array}$ & 121 & 116 & 113 & 112 & 112 & 2.9 & * & NS & NS & NS \\
\hline Acetate & 669 & 672 & 658 & 669 & 675 & 2.8 & NS & NS & $* *$ & NS \\
\hline Propionate & 169 & 174 & 193 & 167 & 171 & 2.3 & $*$ & NS & $* * *$ & NS \\
\hline $\begin{array}{l}\text { Butyrate } \\
\text { (Acetate+butyrate)/ }\end{array}$ & 129 & 122 & 115 & 132 & 122 & 3.0 & NS & NS & $*$ & $*$ \\
\hline Propionate & 4.74 & 4.60 & 4.03 & 4.84 & 4.68 & 0.072 & $*$ & NS & $* * *$ & NS \\
\hline \multicolumn{11}{|l|}{ Digestibility, \% } \\
\hline $\mathrm{OM}$ & 74.9 & 74.8 & 74.7 & 74.0 & 74.3 & 0.69 & NS & NS & NS & NS \\
\hline Nitrogen & 63.7 & 63.1 & 62.7 & 62.8 & 62.2 & 0.61 & NS & NS & NS & NS \\
\hline $\mathrm{NDF}$ & 67.3 & 67.2 & 67.0 & 65.2 & 66.9 & 1.17 & NS & NS & NS & NS \\
\hline
\end{tabular}

\footnotetext{
${ }^{1} \mathrm{Control}=$ No infusion of nutrients; $\mathrm{CN}=300 \mathrm{~g}$ of casein/d infused postruminally; $\mathrm{G}=300 \mathrm{~g}$ of $\mathrm{G}$ infused postruminally; $\mathrm{P}=247 \mathrm{~g}$ of propionic acid infused ruminally, and $\mathrm{S}=270 \mathrm{~g}$ of barley starch infused postruminally.

${ }^{2}$ Orthogonal contrasts: $1=$ Control versus infusions, $2=\mathrm{CN}$ versus $\mathrm{P}+\mathrm{G}+\mathrm{S}, 3=\mathrm{P}$ versus $\mathrm{G}+\mathrm{S}$, and 4 $=\mathrm{G}$ versus $\mathrm{S}$.

${ }^{3} P>0.10$.

${ }^{4}$ Metabolizable energy intake of cows as calculated without infused nutrients on the basis of digestibility of OM measured in the study.

$\dagger P \leq 0.10$.

$* P \leq 0.05$.

$* * P \leq 0.01$.

$* * * P \leq 0.001$.
}

$\mathrm{G}$ and $\mathrm{S}$. This was also reflected in the ratio of lipogenic to glucogenic VFA, which was lower $(P<0.001)$ for $\mathrm{P}$ than for $\mathrm{G}$ and $\mathrm{S}$ treatments. Digestibility of nutrients in the diet was not affected by the infusions $(P>0.05)$. Digestibility of OM and NDF was relatively high, whereas digestibility of CP was low due to the low $\mathrm{CP}$ content of the diet.

The effects of experimental treatments on milk yield and milk composition are presented in Table 3. Infusion of glucogenic substrates tended to $(P=0.12)$ increase milk yield, and also milk lactose content $(P=$ $0.07)$ relative to control. However, the increases in the yields of milk, energy-corrected milk, protein, lactose, and fat were higher $(P<0.01)$ with $\mathrm{CN}$ than with other substrates. Milk protein content increased $(P<0.001)$, and lactose content decreased $(P<0.001)$ with $\mathrm{CN}$ compared with other substrates. Infusion of $P$ into the rumen reduced milk fat yield $(P<0.01)$ and tended to $(P=0.14)$ reduce milk fat content compared with postruminal infusions of $\mathrm{G}$ and S. Milk urea concentrations were low for all treatments. However, $\mathrm{CN}$ increased $(P<0.01)$ milk urea compared with other sub- strates, and $\mathrm{S}$ tended $(P=0.06)$ to decrease milk urea compared with G.

Plasma metabolites and mammary plasma flows are presented in Table 4. Mammary plasma flow on $\mathrm{G}$ was higher $(P<0.05)$ than that on $\mathrm{S}$, both in terms of $\mathrm{L} / \mathrm{d}$ and L/kg of milk. Plasma metabolites were not significantly affected $(P>0.05)$ by the experimental treatments, except that arterial BHBA concentration was reduced $(P<0.05)$ with infusion of substrates, and uptake of $\mathrm{G}$ by the mammary gland was higher $(P<$ $0.05)$ with $\mathrm{G}$ than with $\mathrm{S}$ infusion. Arterial plasma urea and AA concentrations are presented in Table 5. Casein increased $(P<0.001)$ urea, essential AA (EAA) and branched-chain AA, and decreased $(P<0.05)$ nonessential AA (NEAA) relative to other substrates. The proportion of EAA in arterial total AA (TAA) was thus significantly increased $(P<0.001)$ with $\mathrm{CN}$ infusion. Of the individual AA, CN increased $(P<0.05)$ His, Ile, Leu, Lys, Val, Pro, and Orn and decreased $(P<0.05)$ Ala, Glu, Gln, and Gly. Arterial plasma concentrations of Ala and Glu were lower $(P<0.05)$, but that of Gln was higher $(P<0.01)$ with $\mathrm{G}$ than with $\mathrm{S}$ infusion. 
Table 3. Least squares means for milk yield and milk composition.

\begin{tabular}{|c|c|c|c|c|c|c|c|c|c|c|}
\hline & \multicolumn{6}{|c|}{ Nutrients infused ruminally or postruminally ${ }^{1}$} & \multicolumn{4}{|c|}{ Contrast $(P)^{2}$} \\
\hline & Control & $\mathrm{CN}$ & $\mathrm{P}$ & $\mathrm{G}$ & $\mathrm{S}$ & SEM & 1 & 2 & 3 & 4 \\
\hline Milk yield, kg/d & 20.8 & 23.0 & 21.1 & 21.7 & 20.7 & 0.44 & $\mathrm{NS}^{3}$ & $* *$ & NS & NS \\
\hline $\mathrm{ECM}^{4}, \mathrm{~kg} / \mathrm{d}$ & 22.8 & 24.9 & 22.2 & 23.4 & 22.8 & 0.35 & NS & $* * *$ & $\dagger$ & NS \\
\hline \multicolumn{11}{|c|}{ Milk composition, $\mathrm{g} / \mathrm{kg}$} \\
\hline Protein & 33.9 & 35.5 & 33.8 & 33.9 & 33.8 & 0.28 & NS & $* * *$ & NS & NS \\
\hline Lactose & 49.0 & 48.9 & 49.2 & 49.2 & 49.4 & 0.06 & $\dagger$ & $* * *$ & NS & NS \\
\hline Fat & 47.2 & 44.8 & 44.3 & 46.2 & 47.6 & 1.29 & NS & NS & NS & NS \\
\hline \multicolumn{11}{|l|}{ Yield, g/d } \\
\hline Protein & 700 & 816 & 703 & 729 & 698 & 19.6 & NS & $* * *$ & NS & NS \\
\hline Lactose & 1018 & 1122 & 1034 & 1066 & 1021 & 21.0 & NS & $* *$ & NS & NS \\
\hline Fat & 973 & 1025 & 917 & 986 & 976 & 16.4 & NS & $* *$ & $* *$ & NS \\
\hline Urea, mg/L & 101 & 143 & 116 & 116 & 84 & 10.2 & NS & ** & NS & $\dagger$ \\
\hline
\end{tabular}

${ }^{1} \mathrm{Control}=$ No infusion of nutrients; $\mathrm{CN}=300 \mathrm{~g}$ of casein/d infused postruminally; $\mathrm{G}=300 \mathrm{~g}$ of $\mathrm{G}$ infused postruminally; $\mathrm{P}=247 \mathrm{~g}$ of propionic acid infused ruminally, and $\mathrm{S}=270 \mathrm{~g}$ of barley starch infused postruminally.

${ }^{2}$ Orthogonal contrasts: 1 = Control versus infusions, $2=\mathrm{CN}$ versus $\mathrm{P}+\mathrm{G}+\mathrm{S}, 3=\mathrm{P}$ versus $\mathrm{G}+\mathrm{S}$, and $4=\mathrm{G}$ versus $\mathrm{S}$.

${ }^{3} P>0.10$.

${ }^{4} \mathrm{ECM}=$ energy-corrected milk yield, calculated according to Sjaunja et al., (1990).

$\dagger P \leq 0.10$.

$* * P \leq 0.01$.

$* * * P \leq 0.001$.

Calculated mammary AV differences and extractions of plasma AA are given in Tables 6 and 7, respectively. The AV differences and extractions of almost all of the individual AA were significantly higher $(P<$ $0.05)$ with $\mathrm{S}$ than with $\mathrm{G}$ infusion. The extractions of His and Lys were lower $(P<0.05)$ on $\mathrm{CN}$ infusion than on infusions of other substrates. As differences in mammary uptakes of individual AA between the treatments generally were minor; these data are not shown. However, uptake of Ile and Asn were higher $(P<0.05)$ and uptake of branched-chain AA tended to be higher $(P=0.08)$ with $\mathrm{CN}$ than with other sub-

Table 4. Least squares means for mammary plasma flows and plasma metabolites.

\begin{tabular}{|c|c|c|c|c|c|c|c|c|c|c|}
\hline & \multicolumn{6}{|c|}{ Nutrients infused ruminally or postruminally ${ }^{1}$} & \multicolumn{4}{|c|}{ Contrast $(P)^{2}$} \\
\hline \multicolumn{11}{|l|}{ Mammary plasma flow } \\
\hline L/kg milk & 576 & 669 & 728 & 876 & 514 & 96.6 & NS & NS & NS & $*$ \\
\hline \multicolumn{11}{|l|}{ Glucose, mmol/L } \\
\hline Arterial & 3.28 & 3.33 & 3.45 & 3.46 & 3.33 & 0.085 & $\mathrm{NS}^{3}$ & NS & NS & NS \\
\hline \multicolumn{11}{|l|}{$\mathrm{NEFA}, \mu \mathrm{mol} / \mathrm{L}$} \\
\hline Arterial & 85.3 & 78.6 & 72.0 & 66.2 & 72.7 & 7.87 & NS & NS & NS & NS \\
\hline Arteriovenus difference & -16.6 & -14.2 & -18.0 & -26.6 & -17.7 & 7.99 & NS & NS & NS & NS \\
\hline Extraction, \% & -31.3 & -26.8 & -31.8 & -45.5 & -35.6 & 11.34 & NS & NS & NS & NS \\
\hline Uptake, $\mathrm{g} / \mathrm{kg}$ of milk & -2.46 & -2.68 & -4.24 & -6.51 & -2.07 & 1.756 & NS & NS & NS & NS \\
\hline \multicolumn{11}{|l|}{$\mathrm{BHBA}, \mathrm{mmol} / \mathrm{L}$} \\
\hline
\end{tabular}

${ }^{1}$ Control = No infusion of nutrients; $\mathrm{CN}=300 \mathrm{~g}$ of casein/d infused postruminally; $\mathrm{G}=300 \mathrm{~g}$ of $\mathrm{G}$ infused postruminally; $\mathrm{P}=247 \mathrm{~g}$ of propionic acid infused ruminally, and $\mathrm{S}=270 \mathrm{~g}$ of barley starch infused postruminally.

${ }^{2}$ Orthogonal contrasts: $1=$ Control versus infusions, $2=\mathrm{CN}$ versus $\mathrm{P}+\mathrm{G}+\mathrm{S}, 3=\mathrm{P}$ versus $\mathrm{G}+\mathrm{S}$, and $4=\mathrm{G}$ versus $\mathrm{S}$.

${ }^{3} P>0.10$.

$* P \leq 0.05$. 
Table 5. Least squares means for arterial plasma AA and urea concentration $(\mu M)$.

\begin{tabular}{|c|c|c|c|c|c|c|c|c|c|c|}
\hline \multirow[b]{2}{*}{$\mathrm{AA}^{3}$} & \multicolumn{6}{|c|}{ Nutrients infused ruminally or postruminally ${ }^{1}$} & \multicolumn{4}{|c|}{ Contrast $(P)^{2}$} \\
\hline & Control & $\mathrm{CN}$ & $\mathrm{P}$ & G & $\mathrm{S}$ & SEM & 1 & 2 & 3 & 4 \\
\hline Arg & 67 & 71 & 65 & 64 & 70 & 3.4 & $\mathrm{NS}^{4}$ & NS & NS & NS \\
\hline His & 19 & 43 & 19 & 19 & 20 & 2.0 & $*$ & $* * *$ & $\mathrm{NS}$ & NS \\
\hline Ile & 110 & 122 & 102 & 101 & 107 & 4.7 & $\mathrm{NS}$ & $* * *$ & $\mathrm{NS}$ & NS \\
\hline Leu & 101 & 130 & 98 & 91 & 103 & 4.9 & NS & $* * *$ & NS & NS \\
\hline Lys & 83 & 103 & 84 & 84 & 88 & 3.9 & NS & $* *$ & NS & NS \\
\hline Met & 24 & 25 & 26 & 25 & 25 & 1.0 & NS & NS & NS & NS \\
\hline Phe & 43 & 42 & 43 & 42 & 45 & 1.5 & NS & NS & NS & NS \\
\hline Thr & 110 & 112 & 115 & 114 & 118 & 5.1 & NS & NS & NS & NS \\
\hline Trp & 36 & 34 & 36 & 34 & 37 & 1.5 & NS & NS & NS & NS \\
\hline Val & 201 & 241 & 189 & 181 & 197 & 10.4 & NS & $* *$ & NS & NS \\
\hline $\mathrm{Ala}$ & 272 & 235 & 268 & 259 & 277 & 4.9 & $*$ & $* * *$ & NS & $*$ \\
\hline Asp & 6.1 & 5.7 & 5.8 & 5.9 & 6.8 & 0.38 & NS & NS & NS & $\mathrm{NS}$ \\
\hline Asn & 56 & 60 & 57 & 59 & 61 & 2.2 & NS & NS & NS & NS \\
\hline Cys & 21 & 22 & 20 & 19 & 21 & 0.8 & $\mathrm{NS}$ & $\dagger$ & NS & NS \\
\hline Glu & 68 & 60 & 66 & 65 & 71 & 1.1 & $\dagger$ & $* * *$ & NS & $* *$ \\
\hline Gln & 254 & 229 & 258 & 278 & 253 & 5.5 & NS & $* * *$ & NS & $* *$ \\
\hline Gly & 320 & 272 & 293 & 326 & 337 & 14.6 & NS & $*$ & NS & $\mathrm{NS}$ \\
\hline Pro & 70 & 93 & 66 & 69 & 71 & 5.2 & NS & $* *$ & NS & NS \\
\hline Ser & 113 & 103 & 111 & 115 & 119 & 5.9 & NS & NS & NS & NS \\
\hline Cit & 63 & 64 & 55 & 63 & 63 & 4.0 & $\mathrm{NS}$ & NS & NS & $\mathrm{NS}$ \\
\hline Orn & 41 & 49 & 38 & 63 & 43 & 1.9 & NS & $* *$ & NS & $\mathrm{NS}$ \\
\hline Tau & 43 & 39 & 41 & 39 & 45 & 2.0 & NS & NS & NS & NS \\
\hline Tyr & 47 & 52 & 50 & 50 & 50 & 2.4 & NS & NS & NS & $\mathrm{NS}$ \\
\hline 3Methis & 4.0 & 3.1 & 3.2 & 3.4 & 4.1 & 0.57 & NS & $\mathrm{NS}$ & NS & NS \\
\hline BCAA & 412 & 493 & 389 & 372 & 406 & 19.4 & NS & $* *$ & NS & NS \\
\hline EAA & 795 & 922 & 777 & 754 & 810 & 31.7 & NS & $* *$ & NS & NS \\
\hline NEAA & 1227 & 1133 & 1196 & 1247 & 1266 & 29.7 & NS & $*$ & NS & NS \\
\hline TAA & 2022 & 2055 & 1973 & 2001 & 2076 & 53.4 & NS & $\mathrm{NS}$ & NS & NS \\
\hline EAA/TAA & 0.393 & 0.451 & 0.393 & 0.379 & 0.389 & 0.0080 & NS & $* * *$ & NS & NS \\
\hline Urea & 1979 & 2246 & 1715 & 1753 & 1572 & 73.9 & $\dagger$ & $* * *$ & NS & NS \\
\hline
\end{tabular}

${ }^{1}$ Control = No infusion of nutrients; $\mathrm{CN}=300 \mathrm{~g}$ of casein/d infused postruminally; $\mathrm{G}=300 \mathrm{~g}$ of $\mathrm{G}$ infused postruminally; $\mathrm{P}=247 \mathrm{~g}$ of propionic acid infused ruminally, and $\mathrm{S}=270 \mathrm{~g}$ of barley starch infused postruminally.

${ }^{2}$ Orthogonal contrasts: $1=$ Control versus infusions, $2=\mathrm{CN}$ versus $\mathrm{P}+\mathrm{G}+\mathrm{S}, 3=\mathrm{P}$ versus $\mathrm{G}+\mathrm{S}$, and $4=\mathrm{G}$ versus $\mathrm{S}$.

${ }^{3} \mathrm{BCAA}=$ branched-chain AA (Ile, Leu, and Val), EAA = essential AA (Arg, His, Ile, Leu, Lys, Met, Phe, Thr, Trp, and Val), NEAA = nonessential AA (Ala, Asn, Asp, Cys, Gln, Glu, Gly, Pro, Ser, and Tyr), and TAA $=$ EAA + NEAA

${ }^{4} P>0.10$.

$\dagger P \leq 0.10$.

$* P \leq 0.05$.

$* * P \leq 0.01$

$* * * P \leq 0.001$.

strates. Also, uptakes of Leu and Lys were higher ( $P$ $<0.05$ ), and uptakes of Arg and Phe tended to be higher $(P=0.07)$ with $\mathrm{G}$ than with $\mathrm{S}$ infusion. Uptakes of TAA $(38.0,37.9,35.0,38.9$, and $40.0 \mathrm{~g} / \mathrm{kg}$ of milk [SEM 1.87] for control, $\mathrm{CN}, \mathrm{P}, \mathrm{G}$, and $\mathrm{S}$ treatments, respectively) tended $(P=0.09)$ to be lower with $\mathrm{P}$ than with $\mathrm{G}$ and $\mathrm{S}$ infusions.

\section{DISCUSSION}

\section{Characteristics of the Basal Diet}

Assuming metabolizable energy concentration of the experimental diet $(11.2 \mathrm{MJ} / \mathrm{kg} \mathrm{DM})$ on the basis of the digestibility of OM measured, and an increment of an average $4.2 \mathrm{MJ} / \mathrm{d}$ from infused substrates, cows consumed metabolizable energy slightly in excess of the requirements $(106,102,110,109$, and $104 \%$ for treatments control, CN, P, G, and S, respectively). As the CP content of the grass silage was lower than expected, average dietary CP content (13.4\%) was somewhat lower than targeted (14 to $15 \%$ ) even though rapeseed meal was included in the concentrate mixture. That relatively low dietary $\mathrm{CP}$ content was on target in the present study was caused by the need to avoid excess bypass protein in the diet. Calculated supply of AA absorbed from the small intestine on control diet was adequate to fulfill the requirements for observed milk production (Tuori et al., 2000), but 
Table 6. Least squares means for mammary arteriovenous difference $(\mu M)$ of plasma AA.

\begin{tabular}{|c|c|c|c|c|c|c|c|c|c|c|}
\hline \multirow[b]{2}{*}{$\mathrm{AA}^{3}$} & \multicolumn{6}{|c|}{ Nutrients infused ruminally or postruminally ${ }^{1}$} & \multicolumn{4}{|c|}{ Contrast $(P)^{2}$} \\
\hline & Control & $\mathrm{CN}$ & $\mathrm{P}$ & G & $\mathrm{S}$ & SEM & 1 & 2 & 3 & 4 \\
\hline Arg & 31.0 & 25.7 & 25.8 & 24.7 & 31.8 & 2.53 & $\mathrm{NS}^{4}$ & NS & NS & $\dagger$ \\
\hline His & 10.9 & 9.8 & 9.4 & 8.3 & 12.8 & 1.24 & NS & NS & NS & * \\
\hline Ile & 36.4 & 38.1 & 30.5 & 27.6 & 41.2 & 4.11 & NS & $\mathrm{NS}$ & NS & $*$ \\
\hline Leu & 50.3 & 53.6 & 44.8 & 42.5 & 54.2 & 3.24 & NS & NS & NS & $*$ \\
\hline Lys & 45.4 & 43.7 & 39.9 & 38.4 & 48.2 & 2.96 & NS & NS & NS & $*$ \\
\hline Met & 10.9 & 11.3 & 9.2 & 9.1 & 13.0 & 0.69 & NS & NS & NS & $* * *$ \\
\hline Phe & 18.2 & 17.2 & 15.6 & 14.3 & 20.3 & 1.46 & NS & NS & NS & $*$ \\
\hline Thr & 26.5 & 23.4 & 18.7 & 16.1 & 29.9 & 4.17 & NS & NS & NS & * \\
\hline Trp & 4.6 & 3.2 & 2.5 & 0.1 & 6.2 & 1.42 & NS & NS & NS & $*$ \\
\hline Val & 48.3 & 43.4 & 37.4 & 33.1 & 55.7 & 7.25 & NS & NS & NS & $\dagger$ \\
\hline Ala & 30.5 & 5.8 & 11.1 & 29.2 & 45.0 & 12.32 & NS & NS & NS & NS \\
\hline Asp & 2.6 & 2.2 & 2.2 & 2.1 & 3.4 & 0.36 & NS & NS & NS & $*$ \\
\hline Asn & 14.5 & 16.8 & 11.1 & 9.8 & 18.9 & 1.57 & NS & NS & NS & $* * *$ \\
\hline Cys & 1.4 & 0.2 & 0.1 & -0.4 & 2.1 & 0.78 & NS & NS & NS & $\dagger$ \\
\hline Glu & 41.6 & 38.6 & 44.2 & 40.2 & 50.1 & 1.79 & NS & $*$ & NS & $* *$ \\
\hline Gln & 59.8 & 50.0 & 43.0 & 50.0 & 64.0 & 7.53 & NS & NS & NS & NS \\
\hline Gly & 16.3 & -2.9 & -5.3 & -5.9 & 23.7 & 12.76 & NS & NS & NS & NS \\
\hline Pro & 9.4 & 8.0 & 3.7 & 4.0 & 12.0 & 3.91 & NS & NS & NS & NS \\
\hline Ser & 12.2 & 14.9 & 5.7 & 3.5 & 19.8 & 4.57 & NS & NS & NS & $*$ \\
\hline Cit & 4.4 & 0.2 & 2.5 & -0.4 & 6.1 & 2.79 & NS & NS & NS & NS \\
\hline Orn & 19.0 & 16.3 & 15.2 & 15.1 & 20.4 & 1.71 & NS & NS & NS & $\dagger$ \\
\hline Tau & 2.7 & -0.8 & -0.2 & -1.0 & 3.6 & 2.11 & NS & NS & NS & NS \\
\hline Tyr & 17.9 & 16.0 & 14.3 & 11.8 & 19.3 & 2.08 & NS & NS & NS & * \\
\hline 3Methis & 0.2 & -0.4 & 0.0 & -0.1 & 0.8 & 0.57 & NS & NS & NS & NS \\
\hline BCAA & 135 & 135 & 113 & 103 & 151 & 14.4 & NS & NS & NS & * \\
\hline EAA & 283 & 269 & 234 & 214 & 313 & 27.5 & NS & NS & NS & * \\
\hline NEAA & 206 & 150 & 130 & 144 & 258 & 38.9 & NS & NS & NS & $\dagger$ \\
\hline TAA & 489 & 419 & 364 & 359 & 571 & 64.4 & NS & NS & NS & * \\
\hline
\end{tabular}

\footnotetext{
${ }^{1}$ Control $=$ No infusion of nutrients; $\mathrm{CN}=300 \mathrm{~g}$ of casein/d infused postruminally; $\mathrm{G}=300 \mathrm{~g}$ of $\mathrm{G}$ infused postruminally; $\mathrm{P}=247 \mathrm{~g}$ of propionic acid infused ruminally, and $\mathrm{S}=270 \mathrm{~g}$ of barley starch infused postruminally.

${ }^{2}$ Orthogonal contrasts: $1=$ Control versus infusions, $2=\mathrm{CN}$ versus $\mathrm{P}+\mathrm{G}+\mathrm{S}, 3=\mathrm{P}$ versus $\mathrm{G}+\mathrm{S}$, and 4 $=\mathrm{G}$ versus $\mathrm{S}$.

${ }^{3} \mathrm{BCAA}=$ branched-chain AA (Ile, Leu, and Val), EAA = essential AA (Arg, His, Ile, Leu, Lys, Met, Phe, Thr, Trp, and Val), NEAA = nonessential AA (Ala, Asn, Asp, Cys, Gln, Glu, Gly, Pro, Ser, and Tyr), and $\mathrm{TAA}=\mathrm{EAA}+\mathrm{NEAA}$.

${ }^{4} P>0.10$

$\dagger P \leq 0.10$.

$* P \leq 0.05$.

$* * P \leq 0.01$

$* * * P \leq 0.001$.
}

the protein balance in the rumen was negative, $-12 \mathrm{~g} /$ $\mathrm{kg}$ of diet DM. Although protein balance in the rumen values as low as $-20 \mathrm{~g} / \mathrm{kg} \mathrm{DM}$ can be accepted without adversely affecting microbial protein synthesis (Huhtanen, 1998), low dietary CP concentration together with low milk and plasma urea concentrations suggest that supply of RDP was possibly limited in the present dietary conditions. On the other hand, supplementing a low protein grass silage-based diet (CP 13.6\%) with urea or rapeseed feed did not affect rumen microbial protein synthesis or fiber digestibility (Ahvenjärvi et al., 1999). The present rumen ammonia-N concentrations lower than typically found with grass silage diets, even when grass silage is low in $\mathrm{CP}$ and diet is lacking protein supplement (Vanhatalo et al., 1999b; Huhta- nen et al., 2002), may indicate a potentially efficient microbial protein synthesis. However, further reduced ammonia concentration due to infused substrates, especially with CN infusion, was opposite to earlier findings with a larger amount of CN (400 g/d) (Huhtanen et al., 1997). This suggests that all the recycled urea potentially available was used for microbial protein synthesis in the rumen.

Excluding treatment $P$, the rumen fermentation pattern of experimental diets (mean: acetate-propionatebutyrate $671-170-126 \mathrm{mmol} / \mathrm{mol}$ ) was typical for cows fed restrictively fermented silage with a low molar proportion of propionate in VFA (Huhtanen, 1998). As expected, infusion of $\mathrm{P}$ into the rumen increased the proportion of propionate in the rumen VFA. 
Table 7. Least squares means for extraction (AV difference/arterial concentration) of plasma AA by the mammary gland $(\%)$.

\begin{tabular}{|c|c|c|c|c|c|c|c|c|c|c|}
\hline \multirow[b]{2}{*}{$\mathrm{AA}^{3}$} & \multicolumn{6}{|c|}{ Nutrients infused ruminally or postruminally ${ }^{1}$} & \multicolumn{4}{|c|}{ Contrast $(P)^{2}$} \\
\hline & Control & $\mathrm{CN}$ & $\mathrm{P}$ & $\mathrm{G}$ & $\mathrm{S}$ & SEM & 1 & 2 & 3 & 4 \\
\hline Arg & 47.4 & 36.3 & 40.4 & 38.9 & 48.5 & 3.47 & $\mathrm{NS}^{4}$ & NS & NS & $\dagger$ \\
\hline His & 58.0 & 24.0 & 53.8 & 49.8 & 64.4 & 4.53 & NS & $* * *$ & NS & $*$ \\
\hline Ile & 33.1 & 31.0 & 30.6 & 27.5 & 39.1 & 4.04 & NS & NS & NS & $\dagger$ \\
\hline Leu & 49.6 & 41.1 & 46.4 & 47.0 & 53.3 & 3.41 & NS & NS & NS & NS \\
\hline Lys & 54.6 & 42.3 & 48.2 & 46.2 & 56.0 & 2.78 & NS & $*$ & NS & $*$ \\
\hline Met & 47.4 & 46.5 & 38.3 & 39.2 & 52.2 & 3.02 & NS & NS & NS & $*$ \\
\hline Phe & 42.8 & 40.6 & 37.0 & 34.8 & 44.5 & 3.01 & NS & NS & NS & $*$ \\
\hline Thr & 24.3 & 20.9 & 17.7 & 14.9 & 25.5 & 3.34 & NS & NS & NS & $\dagger$ \\
\hline Trp & 13.0 & 9.3 & 7.2 & -0.2 & 16.3 & 3.95 & NS & NS & NS & $*$ \\
\hline Val & 24.0 & 17.6 & 20.3 & 18.1 & 28.8 & 3.48 & NS & NS & NS & NS \\
\hline Ala & 10.8 & 1.7 & 4.4 & 12.5 & 16.7 & 4.88 & NS & NS & NS & NS \\
\hline Asp & 42.5 & 37.6 & 38.1 & 36.0 & 49.2 & 3.27 & NS & NS & NS & $*$ \\
\hline Asn & 26.0 & 28.3 & 20.3 & 17.2 & 30.6 & 2.20 & NS & NS & NS & $* *$ \\
\hline Cys & 7.2 & 0.8 & 0.4 & -2.1 & 10.6 & 3.67 & NS & NS & NS & $*$ \\
\hline Glu & 63.6 & 65.8 & 66.4 & 63.1 & 71.9 & 1.93 & NS & NS & NS & $* *$ \\
\hline Gln & 24.7 & 22.6 & 17.0 & 19.2 & 26.0 & 2.41 & NS & NS & $\dagger$ & NS \\
\hline Gly & 5.2 & -1.5 & -1.7 & -27.2 & 6.4 & 3.96 & NS & NS & NS & NS \\
\hline Pro & 13.5 & 8.1 & 5.9 & 4.6 & 16.2 & 5.12 & NS & NS & NS & NS \\
\hline Ser & 11.5 & 16.5 & 6.1 & 3.7 & 16.7 & 3.54 & NS & $\dagger$ & NS & $*$ \\
\hline Cit & 8.0 & 0.0 & 3.6 & -1.4 & 10.3 & 4.48 & NS & NS & NS & $\dagger$ \\
\hline Orn & 47.2 & 32.6 & 39.9 & 40.0 & 50.2 & 3.55 & NS & $*$ & NS & $\dagger$ \\
\hline Tau & 6.9 & -2.2 & -1.1 & -4.0 & 7.3 & 4.99 & NS & NS & NS & NS \\
\hline Tyr & 38.5 & 30.8 & 30.4 & 23.8 & 38.6 & 4.38 & NS & NS & NS & $*$ \\
\hline 3Methis & 5.0 & -10.9 & 1.8 & -4.6 & 10.2 & 11.58 & NS & NS & NS & NS \\
\hline BCAA & 32.7 & 27.1 & 29.5 & 27.7 & 37.8 & 3.52 & NS & NS & NS & $\dagger$ \\
\hline EAA & 35.6 & 28.9 & 30.7 & 28.4 & 39.1 & 3.30 & NS & NS & NS & * \\
\hline NEAA & 16.9 & 13.1 & 11.1 & 11.8 & 20.3 & 2.91 & NS & NS & NS & $\dagger$ \\
\hline TAA & 24.3 & 20.2 & 18.8 & 18.0 & 27.4 & 2.96 & NS & NS & NS & $\dagger$ \\
\hline
\end{tabular}

${ }^{1}$ Control $=$ No infusion of nutrients $; \mathrm{CN}=300 \mathrm{~g}$ of casein/d infused postruminally; $\mathrm{G}=300 \mathrm{~g}$ of $\mathrm{G}$ infused postruminally; $\mathrm{P}=247 \mathrm{~g}$ of propionic acid infused ruminally, and $\mathrm{S}=270 \mathrm{~g}$ of barley starch infused postruminally.

${ }^{2}$ Orthogonal contrasts: $1=$ Control versus infusions, $2=\mathrm{CN}$ versus $\mathrm{P}+\mathrm{G}+\mathrm{S}, 3=\mathrm{P}$ versus $\mathrm{G}+\mathrm{S}$, and 4 $=\mathrm{G}$ versus $\mathrm{S}$.

${ }^{3} \mathrm{BCAA}=$ branched-chain AA (Ile, Leu, and Val), EAA = essential AA (Arg, His, Ile, Leu, Lys, Met, Phe, Thr, Trp, and Val), NEAA = nonessential AA (Ala, Asn, Asp, Cys, Gln, Glu, Gly, Pro, Ser, and Tyr), and $\mathrm{TAA}=\mathrm{EAA}+\mathrm{NEAA}$.

$$
\begin{aligned}
& { }^{4} P>0.10 . \\
& \dagger P \leq 0.10 . \\
& * P \leq 0.05 . \\
& * * P \leq 0.01 . \\
& * * * P \leq 0.001 .
\end{aligned}
$$

\section{Production Responses to Glucogenic Substrates}

Control versus glucogenic substrates. In agreement with results of Kim et al. (2000), infusion of glucogenic substrates failed to cause any significant increases in milk, protein, or lactose yields, suggesting that $\mathrm{G}$ supply did not primarily limit milk production in the present study. Calculations based on stoichiometric principles demonstrated that, depending on the method of computation, the supply of $\mathrm{G}$ on a diet similar to the present study was suboptimal when milk yield exceeded 20 or $25 \mathrm{~kg} / \mathrm{d}$ (Huhtanen, 1998). The production level of cows achieved in the present study (less than $23 \mathrm{~kg} /$ d) was thus probably not quite optimal for challenging the hypothesis presented. On the contrary, with cows producing less than $25 \mathrm{~kg} / \mathrm{d}$ ruminal propionate infusion (Huhtanen et al., 1998) or combined postruminal infusion of G and His (Huhtanen et al., 2002) resulted in significant increases in the yields of milk, protein, and lactose.

Casein versus other glucogenic substrates. Large positive responses to postruminal $\mathrm{CN}$ infusions have been observed in contrasting nutritional and physiological states of the cows (see Huhtanen et al., 1997). In the present study, the marginal response to $\mathrm{CN}$ (g of milk protein/g of CN infused) was of 39\% at the high end of the range of 10 to $50 \%$ obtained for $\mathrm{CN}$ infused on grass silage-based diets (Miettinen, 1997). Accordingly, cows produced significantly more milk $(1.8 \mathrm{~kg} / \mathrm{d})$, milk 
protein $(100 \mathrm{~g} / \mathrm{d})$, and lactose $(82 \mathrm{~g} / \mathrm{d})$ with $\mathrm{CN}$ than with other glucogenic substrates. This suggests that even though the basal diet met the calculated requirement of metabolizable protein, the supply of AA was not sufficient to fulfill the AA requirements of the mammary gland.

However, the significantly increased lactose yield with $\mathrm{CN}$ infusion may suggest that $\mathrm{CN}$ provided precursors not only in terms of EAA for milk protein synthesis but also in terms of NEAA for gluconeogenesis in the liver (Miettinen and Huhtanen, 1997). This is supported with the increased EAA, and decreased NEAA together with increased urea concentrations in arterial plasma in response to infused $\mathrm{CN}$ as will be discussed later. That the G supply did not primarily limit milk production became evident from the fact that $\mathrm{CN}$ provided higher lactose yield than other substrates despite providing only approximately half of the G supply provided with other substrates. Attempts to separate milk protein responses due to provision of AA as precursors of milk protein synthesis from those due to the provision of AA as G precursors also indicated that the primary factor limiting milk protein output was the supply of AA rather than supply of G (Kim et al., 2000). In their study, infusions of TAA equivalent to $200 \mathrm{~g}$ of $\mathrm{CN}$ did not, however, increase milk lactose output. The present significant increment in the lactose yield may be explained with a higher dose of CN $(300 \mathrm{~g} / \mathrm{d})$ than TAA $(200 \mathrm{~g} / \mathrm{d})$ infused. The greater AA supply due to a bigger dose of $\mathrm{CN}$ infused may suggest that as soon as AA supply is fulfilled, G supply may also become a limiting factor for a further production response.

The low ratio of increments in protein and lactose yield of $\mathrm{G}$ (0.6) as compared with CN (1.1) infusion may further emphasize that various nutrients, supply of AA with $\mathrm{G}$ containing treatments and supply of $\mathrm{G}$ with $\mathrm{CN}$ treatment, limited further production responses in the present study. This is supported by the results of our recent studies, where simultaneous rather than separate infusion of His and G (Huhtanen et al., 2002) or of $\mathrm{CN}$ and $\mathrm{G}$ (Vanhatalo et al. 1999a) resulted in additive production responses in terms increased yields of milk, protein, and lactose.

Comparison of isoglucogenic substrates: Ruminal versus intestinal supplementation. The only significant difference between the isoglucogenic treatments was that infusion of $\mathrm{P}$ into the rumen was associated with a decreased milk fat yield as compared with abomasal infusions of $\mathrm{G}$ and S. Only a marginal difference in plasma BHBA between ruminally and abomasally supplied substrates does not explain this difference. In the literature, however, both $\mathrm{P}$ and $\mathrm{G}$ infusions induced a decrease in milk fat contents and yields as reviewed by Lemosquet et al. (1997) and Hurtaud et al. (1998).

The absence of decrease in fat yield due to moderate amount of infused $\mathrm{G}(300 \mathrm{~g} / \mathrm{d})$ is in agreement with the results of studies conducted in similar dietary conditions (Vanhatalo et al., 1999a; Kim et al., 2000; Huhtanen et al. 2002). The consistent decreases in milk fat contents and yields with $\mathrm{G}$ substrates in other studies may be explained by the considerably higher infusion rates of $\mathrm{G}$, often exceeding $1 \mathrm{~kg} / \mathrm{d}$ of $\mathrm{G}$ or starch, in dietary conditions in which $G$ supply from the basal diets is presumably much higher than that from the diets based on restrictively fermented grass silage. This may have led to the greatly depressed net contribution of body lipids to milk fat synthesis because of either inhibition of adipose lipolysis or increased adipose lipogenesis (Lemosquet et al., 1997; Hurtaud et al. 1998).

Comparison of isoglucogenic substrates: glucose versus starch. Comparison of $G$ and $S$ infusions yielded no significant differences in production parameters. Slightly higher milk, protein, and lactose yields with G may partly be explained by a slightly lower total $\mathrm{DM}$ and metabolizable energy intake on $\mathrm{S}$ treatment. However, numerically higher arterial G concentration with $G$ may also refer to a more efficient absorption of $\mathrm{G}$ with $\mathrm{G}$ than $\mathrm{S}$. When equal amounts of $\mathrm{G}$ and maize starch were infused postruminally, significantly more $G$ than starch disappeared from the small intestine, suggesting that potential for $\mathrm{G}$ absorption by the small intestine is greater than for starch hydrolysis coupled with G absorption (Kreikemeier and Harmon, 1995). Also, increasing flows of starch to the small intestine have clearly decreased starch digestibility (Kreikemeier et al., 1991). In the present study, only a moderate amount of starch was infused and therefore a high, but not complete digestion of starch could be expected (Kreikemeier et al., 1991). Thus, part of the infused S probably passed the small intestine undigested and was submitted to microbial fermentation in the large intestine as judged from the slightly lower plasma and milk urea concentration on $\mathrm{S}$ than $\mathrm{G}$ infusion.

\section{Plasma Metabolites and AA}

Ørskov et al. (1999) observed that incremental levels of $\mathrm{G}$ infusion with intragastrically nourished steers resulted in reductions in plasma concentrations of BHBA and NEFA, and urinary $\mathrm{N}$ excretion with an inverse trend in plasma $\mathrm{G}$ demonstrating the $\mathrm{N}$-sparing effect of $\mathrm{G}$ on body protein catabolism. In the present study, plasma BHBA, NEFA, and G, due to infusion of glucogenic substrates, changed accordingly, though not always significantly. Similar changes in plasma $G$ and $\mathrm{BHBA}$, as a consequence of a higher proportion of ru- 
men propionate have also been found in cows fed extensively rather than restrictively fermented silage (Miettinen and Huhtanen, 1997; Shingfield et al., 2002). These changes together with a trend $(P=0.10)$ of decreased plasma urea concentration (except for the CN treatment) in the present study may reflect increased availability of $\mathrm{G}$ and decreased release of nutrients from body stores.

Similarly to earlier findings (Choung and Chamberlain, 1993; Miettinen and Huhtanen, 1997), abomasal infusion of CN increased most of the EAA in arterial plasma, suggesting that more AA were available for milk synthesis on $\mathrm{CN}$ than on other treatments. This was also reflected in the significant increase in the arterial EAA to TAA ratio for the $\mathrm{CN}$ treatment. Low arterial plasma concentration of His and a high extraction of His by the mammary gland on treatments other but CN suggest that deficiency of His may have primarily limited milk protein production as recently found on a grass silage based-diet (Vanhatalo et al., 1999b). The decreased NEAA and increased urea concentrations together with increased urea cycle AA, especially that of Orn, in arterial plasma in response to $\mathrm{CN}$ infusion is consistent with increased utilization of NEAA in G synthesis (Miettinen and Huhtanen, 1997). Of the individual NEAA, decreased plasma arterial Ala, Glu, Gln, and Gly with $\mathrm{CN}$ infusion emphasize the role of these particular AA contributing to G synthesis (Bergman and Heitmann, 1978; Black et al., 1990).

Decreased arterial Gly has also been attributed to reduced muscle catabolism and improved protein status of the cows (Bergman and Heitmann, 1978; Mepham, 1982), which seemed to concern not only CN but also $\mathrm{P}$ treatment in the present study. Commensurate with this, abomasal infusions of CN (Miettinen and Huhtanen, 1997) and His (Vanhatalo et al., 1999b), and ruminal infusion of $\mathrm{P}$ (Huhtanen et al., 1998) decreased arterial Gly with grass silage-based diets. Higher uptakes of Asn and branched-chain AA on $\mathrm{CN}$ than on other infusions presumably reflect the capacity of the mammary gland to take up some AA such as branchchain AA and Lys in excess in order to provide intermediates of the glycolytic and TCA pathways, and contribute to the pool of NEAA required for milk protein synthesis (Mepham, 1982).

Despite only small differences in the arterial concentration of AA on $\mathrm{S}$ and $\mathrm{G}$ infusions, AV differences, extractions, and uptakes of EAA and several individual AA as well as mammary plasma flow differed significantly between these treatments. As there was not any significant difference in the milk protein yield between $\mathrm{S}$ and $\mathrm{G}$, it seems that within the given nutritional range the mammary gland was able to adapt to the changing nutrient supply on these two treatments by changing extraction efficiencies of AA and mammary blood flow.

\section{CONCLUSIONS}

Production responses to glucogenic substrates other than $\mathrm{CN}$ were negligible, suggesting that G supply of cows did not primarily limit milk protein synthesis in the present study. Significantly higher production responses, especially that of lactose, to $\mathrm{CN}$ than to other glucogenic substrates coupled with the concentrations of increased arterial EAA and urea, and decreased NEAA with CN treatment, suggest that $\mathrm{CN}$ provided precursors both in terms EAA for milk protein synthesis and NEAA for gluconeogenesis. This puts forward that, although inadequate AA supply was primarily limited production responses, G supply of grass silage fed cows also possibly became inadequate to fulfill the needs of the mammary gland for optimal milk protein synthesis in the present study. The limited supply of AA and possibly the low production levels of cows partly invalidated the hypothesis of monitoring differing glucogenic substrates for studying the most suitable strategy for $\mathrm{G}$ supplementation of grass silage diet. Further studies are needed to examine $\mathrm{G}$ supply of cows fed these diets, especially at early stage of lactation.

\section{ACKNOWLEDGMENTS}

The staff of the experimental stable, led by Aino Matilainen, and laboratory staff, led by Vesa Toivonen, are gratefully acknowledged for their input in conducting the experiment. Barley starch was provided by Primalco Ltd. (Rajamäki, Finland), which is duly acknowledged. This study was partly funded by Raisio Feed Ltd. (Raisio, Finland).

\section{REFERENCES}

Ahvenjärvi, S., A. Vanhatalo, P. Huhtanen, and T. Varvikko. 1999. Effects of supplementation of a grass silage and barley diet with urea, rapeseed meal and heat-moisture-treated rapeseed cake on omasal digesta flow and milk production in lactating dairy cows. Acta Agric. Scand., Sect. A. Anim. Sci. 49:179-189.

Bergman, E. N., and R. N. Heitmann. 1978. Metabolism of amino acids by the gut, liver, kidneys, and peripheral tissues. Fed. Proc. 37:1228-1232.

Black, A. L., R. S. Anan, M. L. Bruss, and C. A. Brown. 1990. Partitioning of amino acids in lactating cows: Oxidation to carbon dioxide. J. Nutr. 120:700-710.

Chamberlain, D. G., and J. J. Choung. 1993. The nutritional value of grass silage. Pages 131-135 in Silage Research 1993. Proc.10th Int. Silage Conf., Dublin, Ireland.

Choung, J.-J., and D. G. Chamberlain. 1993. The effects of abomasal infusions of casein or soya-bean-protein isolate on the milk production of dairy cows in mid-lactation. Br. J. Nutr. 69:103-115.

Danfær, A., V. Tetens, and N. Agergaard. 1995. Review and an experimental study on the physiological and quantitative aspects of gluconeogenesis in lactating ruminats. Comp. Biochem. Physiol. 111B:201-210. 
Hansen, J. L., and E. F. Freier. 1978. Direct assays of lactate, puryvate, $\beta$-hydroxybutyrate and acetoacetate with a centrifugal analyzer. Clin. Chem. 24:15-27.

Huhtanen, P. 1998. Supply of nutrients and productive responses in dairy cows given diets based on restrictively fermented silage. Agric. Food Sci. Finl. 7:219-250.

Huhtanen, P., R. Blauwiekel, and I. Saastamoinen. 1998. Effects of intraruminal infusions of propionate and butyrate with two different protein supplements on milk production and blood metabolites in dairy cows receiving grass silage-based diet. J. Sci. Food Agric. 77:213-222.

Huhtanen, P. J., H. O. Miettinen, and V. F. J. Toivonen. 1997. Effects of silage fermentation and postruminal casein supplementation in lactation dairy cows: 1 . Diet digestion and milk production. J. Sci. Food Agric. 74:450-458.

Huhtanen, P., A. Vanhatalo, and T. Varvikko. 2002. Effects of abomasal infusions of histidine, glucose, and leucine on milk production and plasma metabolites of dairy cows fed grass silage diets. J. Dairy Sci. 85:204-216.

Hurtaud, C., H. Rulquin, and R. Verite. 1998. Effects of level and type of energy source (volatile fatty acids or glucose) on milk yield, composition and coagulating properties of dairy cows. Reprod. Nutr. Dev. 38:315-330.

Jaakkola, S., and P. Huhtanen. 1993. The effects of preservation method and proportion of concentrate on nitrogen digestion and rumen fermentation in cattle. Grass Forage Sci. 48:146-154.

Kim, C.-H., J.-J. Choung, and D. G. Chamberlain. 2000. The effects of intravenous administration of amino acids and glucose on the milk production of dairy cows consuming diets based on grass silage. Grass Forage Sci. 55:173-180.

Kreikemeier, K. K., and D. L. Harmon. 1995. Abomasal glucose, maize starch and maize dextrin infusions in cattle: Small-intestinal disappearance, net portal glucose flux and ileal oligosaccharide flow. Br. J. Nutr. 73:763-772.

Kreikemeier, K. K., D. L. Harmon, R. T. Brandt, Jr., T. B. Avery, and D. E. Johnson. 1991. Small intestinal starch digestion in steers: Effect of various levels of abomasal glucose, corn starch, and corn dextrin infusion on small intestinal disappearance and net glucose absorption. J. Anim. Sci. 69:328-338.

Lemosquet, S., N. Rideau, H. Rulquin, P. Faveridin, J. Simon, and R. Verite. 1997. Effects of a duodenal glucose infusion on the relationship between plasma concentrations of glucose and insulin in dairy cows. J. Dairy Sci. 80:2854-2865.

Mepham, T. B. 1982. Amino acid utilization by lactating mammary gland. J. Dairy Sci. 65:287-298.

Miettinen, H. 1997. Effects of nutrient supply, especially volatile fatty acids, on blood metabolites, mammary nutrient metabolism and milk production in dairy cows. Academic Diss., Univ. of Helsinki, Finland.

Miettinen, H., and P. Huhtanen. 1996. Effects of ruminal propionate to butyrate ratio on milk production and blood metabolites in dairy cows. J. Dairy Sci. 79:851- 861.

Miettinen, H. O., and P. J. Huhtanen. 1997. Effects of silage fermentation and post-ruminal casein supplementation in lactating dairy cows: 2. Energy metabolites and plasma amino acids. J. Sci. Food Agric. 74:459-468.

Nocek, J. E., and S. Tamminga. 1991. Site of digestion of starch in the gastrointestinal tract of dairy cows and its effect on milk yield and composition. J. Dairy Sci. 74:3598-3629.

Ørskov, E. R., D. E. Meehan, N. A. MacLeod, and D. J. Kyle. 1999. Effect of glucose supply on fasting nitrogen excretion and effect of level and type of volatile fatty acid infusion on response to protein infusion in cattle. Br. J. Nutr. 81:389-393.

SAS User's Guide: Statistics, Version 6.12. 1996. SAS Inst. Inc., Cary, NC.

Shingfield, K. J., S. Jaakkola, and P. Huhtanen. 2002. Effect of forage conservation method, concentrate level and propylene glycol on diet digestibility, rumen fermentation, blood metabolite concentrations and nutrient utilisation of dairy cows. Anim. Feed Sci. Technol. 97:1-21.

Sjaunja, L. O., L. Baevre, L. Junkkarinen, J. Pedersen, and J. Setälä. 1990. A Nordic proposal for an energy corrected milk (ECM) formula. Pages 156-157 in 27th Session Int. Comm. Recording and Productivity of Milk Animals. Paris.

Tuori, M., K. Kaustell, J. Valaja, E. Aimonen, E. Saarisalo, and P. Huhtanen. 2000. Rehutaulukot ja ruokintasuositukset. (Feed Tables and Feeding Recommendations). 3rd ed. Yliopistopaino, Helsinki, Finland.

Vanhatalo, A., P. Huhtanen, and T. Varvikko. 1999a. Effect of casein and glucose on production and metabolic responses of dairy cows fed diets based on restrictively fermented grass silage. SouthAfrican J. Anim. Sci. 29(ISRP):263-264. (Abstr.)

Vanhatalo, A., P. Huhtanen, V. Toivonen, and T. Varvikko. 1999b. Response of dairy cows fed grass silage diets to abomasal infusions of histidine alone or in combinations with methionine and lysine. J. Dairy Sci. 82:2674-2685.

van Vuuren, A. M., P. Huhtanen, and J. P. Dulphy. 1995. Improving the feeding and health value of ensiled forages. Pages 279-307 in Recent Developments in the Nutrition of Herbivores. Proc. of the IVth Int. Symp. on the Nutrition of Herbivores. M. Journet, E. Grenet, M.-H. Farce, M. Theriez and C. Demarquilly, eds. INRA, Paris.

Varvikko, T., A. Vanhatalo, T. Jalava, and P. Huhtanen. 1999. Lactation and metabolic responses to graded abomasal doses of methionine and lysine in cows fed grass silage diets. J. Dairy Sci. 82:2659-2673. 